
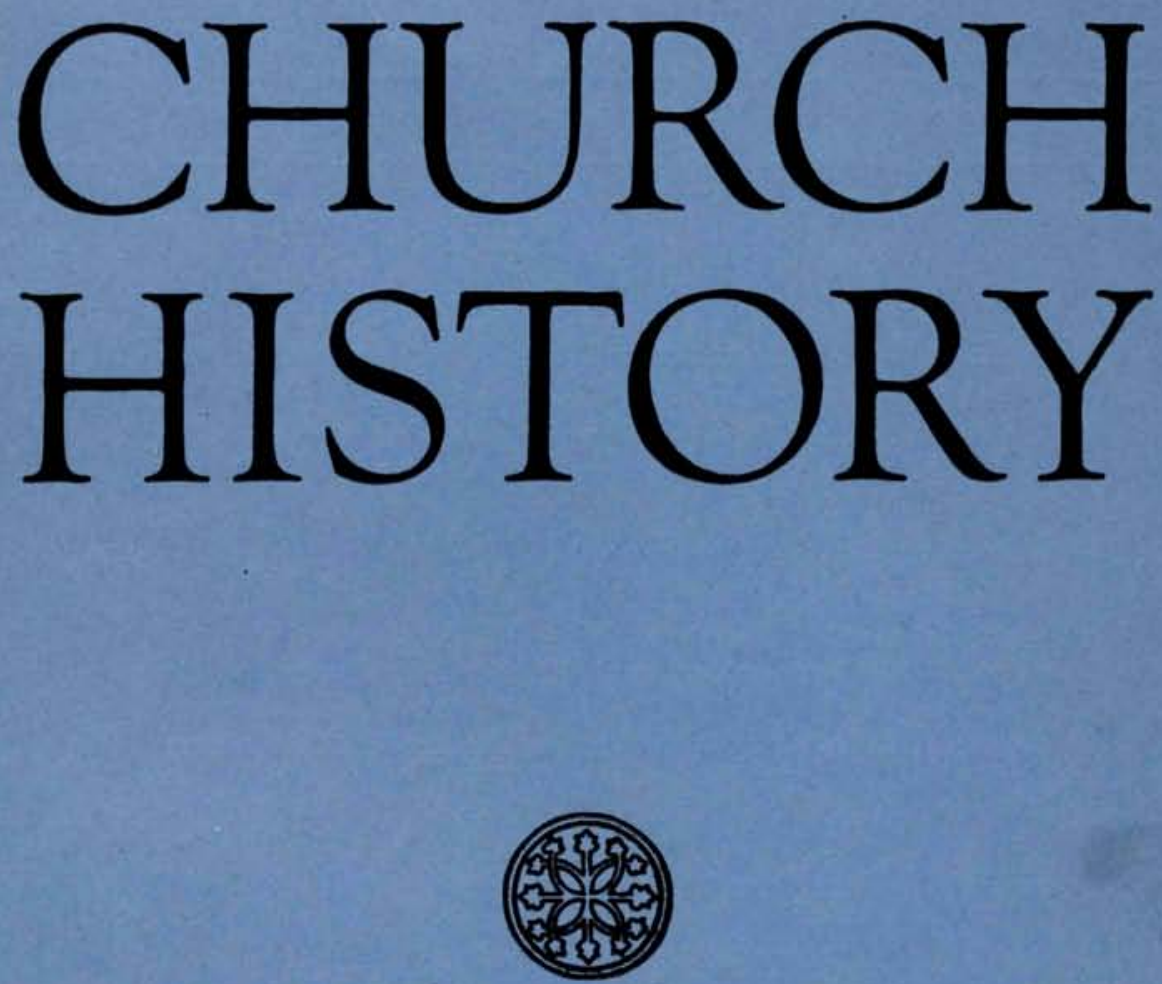

Published by

\title{
THE AMERICAN SOCIETY OF CHURCH HISTORY
}




\section{THE AMERICAN SOCIETY OF CHURCH HISTORY}

FOUNDED BY PHIIIP SCHAFF, 1888: REORGANTZED, 1906: INCORPORATED BY ACT OF THE LEGISLATURE OF NEW YORK, 1916

\section{OFFICERS FOR 1943}

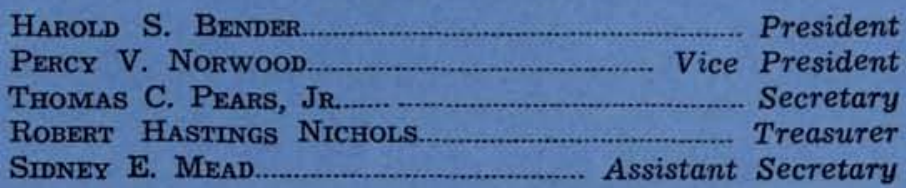

\section{OTHER MEMBERS OF THE COUNCIL}

WIHHELM PAUCK

HERBERT WaLLACE SCHNEIDER

REUBEN E. E. HaRKNESS

Charles H. LytTle

ROLAND H. BaINTON
F. W. BUCKLER

E. R. HARDY, JR.

CyrIL C. Richardson

KENNETH S. LATOURETTE

ERNEST G. ScHWIEBERT

\section{EDITORIAL BOARD OF CHURCH HISTORY}

MATTHEW SPINKA, Managing Editor

ROBERT HASTINGS Nrchols

HAROLD S. BENDER, ex officio

\section{Publication Office, Berne, Indiana}

Executive and Edtorial Office, 92 Sherman Street, Hartford 5, Conn.

Church Hrstory is a quarterly journal published in March, June, September, December by the American Society of Church History. The subscription price is three dollars per year. The price of single copies is seventy-five cents. To foreign countries, the postage of twenty-five cents a year should be added. Subscriptions should be sent to Professor Matthew Spinka, 92 Sherman Street, Hartford 5, Conn, or to Professor Robert Hastings Nichols, 99 Claremont Ave., New York 27, N. Y. Remittances should be made to the order of American Society of Church History.

All communications regarding contributions, book reviews, and all other matters of editorial nature should be sent to Professor Matthew Spinka, 92 Sherman Street, Hartford 5, Conn.

Claims for missing numbers and changes of address should be addressed to Prof. R. H. Nichols, 99 Claremont Ave., New York 27, N. Y.

Entered as second class matter March 9, 1934, at the post office at Berne, Ind., under the Acts of March 3, 1879. 


\section{CHURCH \\ HISTOR Y}

Edited by

Matthew Spinka Robert Hastings Nichols

Harold S. Bender

Volume XII

1943

Published by

THE AMERICAN SOCIETY OF CHURCH HISTORY 


\section{TABLE OF CONTENTS}

\section{ARTICLES}

Pages

Bark, William, The Doctrinal Interests of Marius Mercator 210-216

Batten, J. Minton, Political Factors in Movements Toward Christian Unity in Seventeenth Century Europe $163-176$

Fedotrv, George P., Religious Backgrounds of Russian Culture $35-51$

Hardy, Edwin Rochie, Jr., Servant of the Servants of God

Hudson, Winthrop S., Gerrard Winstanley and the Early Quakers

Latourette, Kenneth Scott, The Christian Church in the Last Seventy Years

McNeill, John T., The Doctrine of the Ministry in Reformed Theology

Michaelides, George P., The Greek Orthodox Position on the Confession of Cyril Lucaris

Minllett, Charles F., English Presbyterians and the Scottish Disruption: the Legal Phase

Pride, Ellen Perry, Ecclesiastical Legislation on Education, A.D. $300-1200$

Schoenbohm, Richard, Music in the Lutheran Church Before and at the Time of $\mathrm{J}$. S. Bach

Schwisbert, E. G., The Medieval Pattern in Luther's Views of tlie State

Spinka, Matthew, Peter Chelčický, Spiritual Father of the Unitas Fratrum

\section{Minutes of the Society}

Minutes of the Fifty-Fourth Meeting of the Society and of the Council, December, 1942

\section{Members OF THE SOCIETy}

List of Members 


\section{BOOK REVIEWS}

Abbott, Nabia, Aishah, the Beloved of Mohammed

Pages

Abbott, Nabia, Aisthah, the Beloued of Mohamed 131-132

71.72

Bainton, Roland H., and Gibbons, Lois O., George Lincoln Burr

297-299

Baron, Salo, The Jewish Community: Its History and Structure to the American Revolution

Beardsley, Frank Grenville, Religions Progress Through Religious Revivals 228-229

Braegelmanu, Sister Athanasius, O.S.B., The Life and Writings of Saint Ildefonsus of Toledo $220 \cdot 2 \cdot 21$

brickmall, Benjamin, An Introduction to Francesco Patrizi's Nova de Universis Philosophia

Burckhardt, Jacob, Force and Freedom

Cabaniss, Allen, Life and Thought of a Country Preacher 130-131

Carruthers, S. W., The Everyday Work of the Westminster Assembly

$73-74$

Curtis, William Redmond, The Lambeth Confercnces 224-226

Davis, Arthur Paul, Isaac Watts 74

Eller, Paul H., History of Lvangelical Missions

138-139

Farrow, John, Pageant of the Popes

$72-73$

Filson, Floyd V., One Lord One Faith 294-295 219-220

Gallagher, J. L., transl., The China That Was 136-137

Gegenheimer, Albert F., William Smith 297

Holsapple, Lloyd B., Constantine the Great 220

Höye, Bjarne and Ager, Trygve M., The Fight of the Norwegian Church against Nazism

231

134

Hudson, Winthrop S., John Ponet (1516?-1576)

Klausner, Joseph, From Jesus to Paul 292-294

Knox, John, Marcion and the New Testament

Latourette, Kenneth Scott, The Great Century in the Americas, Australasia, and Africa, A.D. 1800-A.D. 1914

Mead, Sidney Earl, Nathaniel William Taylor, 1766-1858

Mueller, John Theo., Early Missionary Endeavors Among the American Indians

Newman, Abraham, A., The Jews in Spain

Norwood, Frederick A., The Reformation Refugees as an Economic Force .....

Olmstead, A. T., Jesus, in the Light of History

Post, Albert, Popular Freethought in America, 1825-1850

Rowbotham, Arnold, H., Missionary and Mandarin

Spinka, Matthew, John Amos Comenius: That Incomparable Moravian ......

Tappert, Theodore G. and Doberstein, John W., transl., The Journals of Henry Melchior Muhlenberg

Tschan, Francis J., Saint Bernward of Hildesheim

Willoughby, Harold R., The First Authorized English Bible and the Cranmer Preface

Zabriskie, Alexander C., Arthur Selden Lloyd 


\section{THE AMERICAN SOCIETY OF CHURCH HISTORY}

FOUNDED BY PHILIP SCHAFF, 1888: REORGANIZED, 1906: INCORPORATED BY ACT OF THE LEGISLATURE OF NEW YORK, 1916

\section{OFFICERS FOR 1943}

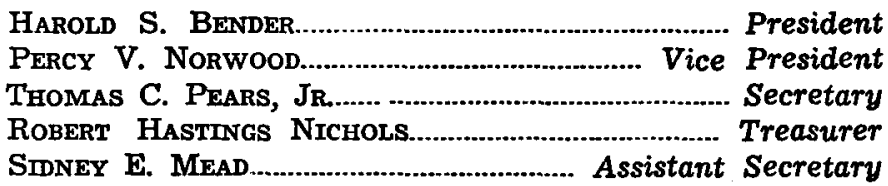

OTHER MEMBERS OF THE COUNCIL

Wilhelm Pauck

HERBERT WALLACE SCHNEIDER

REUBEN E. E. HARKNESS

Charles H. LyttLE

ROLAND H. BatNTON
F. W. BUCKLER

E. R. HARDY, JR.

Cyric C. Richardson

KENNETH S. LATOURETTE

ERNEST G. SchWITRERT

\section{EDITORIAL BOARD OF CHURCH HISTORY}

MatTHEW SPINKA, Managing Editor

ROBERT Hastivas Nichols

HAROLD S. BENDER, ex officio

Publication Office, Berne, Indiana

Executive and Editorial Office, 92 Sherman Street, Hartford 5, Conn. 


\section{CHURCH HISTORY}

EDITORIAL BOARD

Matraew SpInka, Managing Editor

Robert Hastings Nichots

Harold S. BENDER, ex officio

\section{TABLE OF CONTENTS}

Ecclesiastical Legislation on Education,

A. D. $300-1200$

Ellen Perry Pride

English Presbyterians and the Scottish

Disruption: The Legal Phase

Charles F. Mullett

Peter Chelčický, Spiritual Father of the LNITAS FRATRUM

Matthew Spinka 


\section{CONTENTS}

\section{BOok Reviews}

Krnusner, Joseph, From Jesus to Paul

Paul Schubert

Farrow, John, Pageant of the Popes Matthew Spinka

Srreb, F. J., transl., The Confessions of Augustine Matthew Spinka

Norwood, Frederick A., The Reformation Refugees as an Economic Force Quirinus Breen

Gegenhermer, Albert F., William Smith George H. Bost

Bainton, Roland H., and Gibbons, Lois O., George Lincoln Burr Charles H. Lyttle 